\title{
SYNTHESIS OF NANOSIZED METALLIC PARTICLES FROM AN AEROSOL
}

\author{
Srećko R. Stopić \\ IME Process Metallurgy and Metal Recycling, \\ RWTH Aachen University, Aachen, Germany
}

FIELD: Materials

DOI: 10.5937/vojtehg61-3601

ARTICLE TYPE: Review Paper

Abstract:

The synthesis of metallic nanoparticles from the precursor solution of salts using the ultrasonic spray pyrolysis method was considered in this work. During the control of process parameters (surface tension and density, the concentration of solution, residence time of aerosol in the reactor, presence of additives, gas flow rate, decomposition temperature of aerosol, type of precursor and working atmosphere) it is possible to guide the process in order to obtain powders with such a morphology which satisfies more complex requirements for the desired properties of advanced engineering materials. Significant advance in the improvement of powder characteristics (lower particles sizes, better spheroidity, higher surface area) was obtained by the application of the ultrasonic generator for the preparation of aerosols. Ultrasonic spray pyrolysis is performed by the action of a powerful source of ultrasound on the corresponding precursor solution forming the aerosol with a constant droplet size, which depends on the characteristics of liquid and the frequency of ultrasound. The produced aerosols were transported into the hot reactor, which enables the reaction to occur in a very small volume of a particle and formation of nanosized powder. Spherical, nanosized particles of metals (Cu, Ag, Au, Co) were produced with new and improved physical and chemical characteristics at the IME, RWTH Aachen University. The high costs associated with small quantities of produced nanosized particles represent a limitation of the USP-method. Therefore, scale up of the ultrasonic spray pyrolysis was performed as a final target in the synthesis of nanosized powder.

Ključne reči: Aerosol, nanoparticles, ultrasound, spray, pyrolysis, MMCT transition.

\footnotetext{
*ACKNOWLEDGMENT: I would like to thank Prof. Ilija Ilic, Faculty of Technology and Metallurgy of the Belgrade University, Prof. Dragan Uskokovic and Prof. Olivera Milosevic, Institute of Technical Sciences of the Serbian Academy of Sciences and Arts in Serbia for my initial steps in the USP process and their support in the synthesis of metallic nanosized particles. My thanks for the continuous support are especially addressed to Prof. Dr.-Ing. Dr. h. c. Bernd Friedrich, the doctoral candidates Jelena Bogovic and Albrecht Schwinger, and our technicians Dieter Leimbach and Friedrich Rosen at the IME, RWTH Aachen University.
}

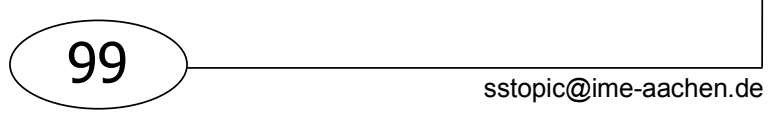




\section{Nanoparticles- Properties and synthesis}

erosol represents a substance consisting of very fine particles of a liquid or solid suspended in a gas. Mist, which consists of very fine droplets of water in the air, is also an aerosol. PRIZnano (Prizma, Kragujevac) is a high frequency ultrasonic atomizer of liquids used in the process of gaining nanopowder by deploying ultrasonic spray pyrolysis (as shown in Fig. 1).
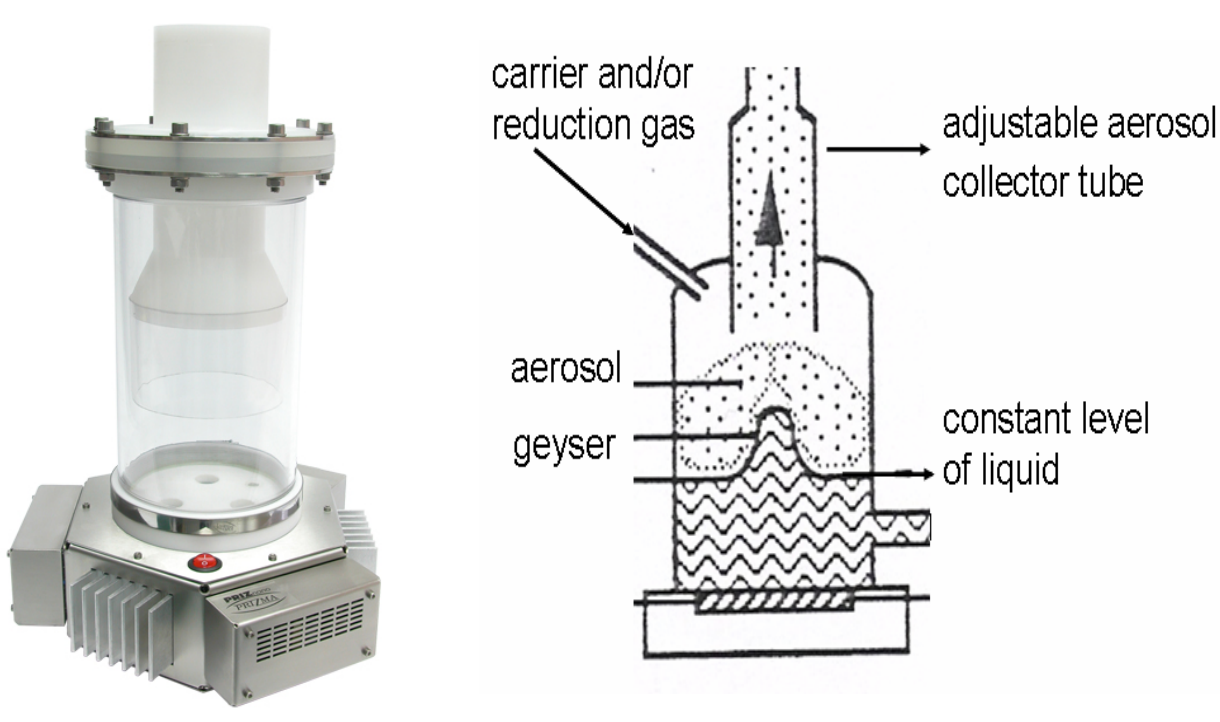

Fig. 1 - Aerosol production by the ultrasonic atomiser by Prizma, Kragujevac Slika 1 - Proizvodnja aerosola pomocu ultrazvucnog rasprsivaca Prizma, Kragujevac

During high frequency ultrasonic atomization, a piezoelectric crystal coated with glass installed at the bottom of the sonication vessel vibrating at a frequency of $1.7 \mathrm{MHz}$ supplies the energy required for atomizing the liquid (Fig. 1). When the ultrasonic vibrations are sufficiently intense, a fountain rises from the surface of the liquid due to acoustic pressure waves and breaks up at the apex as a result of the gravitational effect (1999, http://www.prizma.rs/ml/index.php).

The word "Nano" (symbol n) is derived from the Greek "dwarf" and was firstly officially confirmed as standard in 1960. This prefix in the metric system denotes a factor of $10^{-9}$ or 0.000000001 . It is frequently encountered in science and electronics for prefixing units of time and length. Nanostructured materials have shown an explosion of scientific 
and industrial interest over the last few decades (Rittner, Abraham, 1998, pp.37-47), (BMBF, 2006), (Lüchinger, et al, 2010, pp.89-101), (Cammer, 2009, pp.214-217), (Stopic, et al, 2010, pp.419-426), (Dittrich, et al, 2011, pp.1065-1076), (Messing, et al, 1993, pp.2707-2726).

These unique materials are distinguished from conventional polycrystalline micron materials by their fine crystallite sizes. A significant higher fraction of atoms are located at the surface of nanosized particulates as compared to conventional prepared powders.

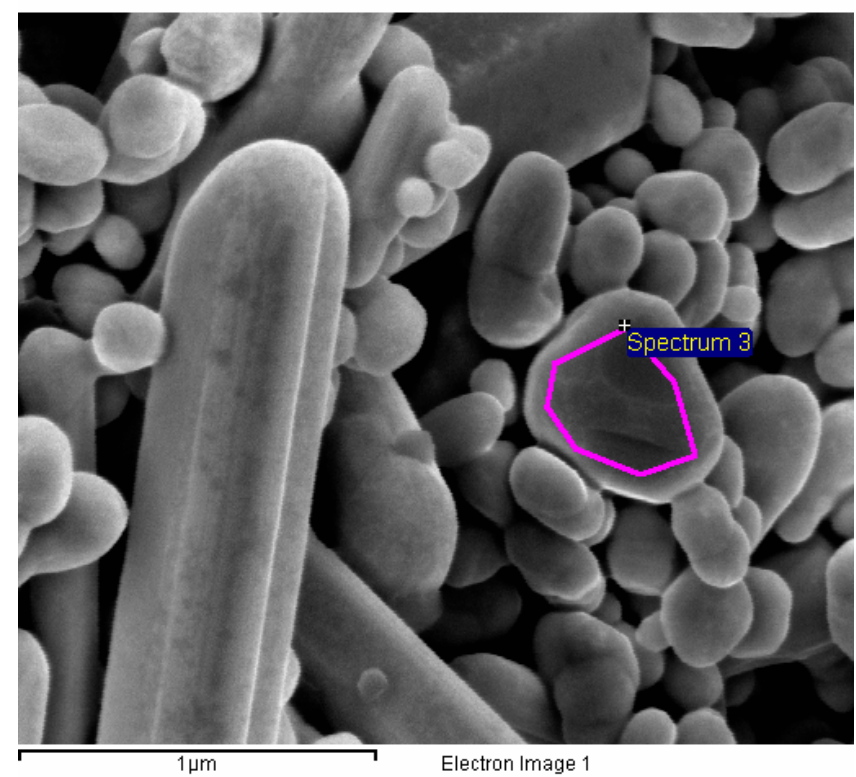

Figure 2 - Nanogold produced from an old jewellery scrap by the USP - method (Rudolf, et al, 2012, pp.195-212)

Slika 2 - Nanozlato proizvedeno iz starog nakita pomocu USP - postupka (Rudolf, et al, 2012, pp.195-212)

This structural characteristic is responsible for the enhanced reactivity of nanoparticles compared to conventional materials. Changes in properties at the nano-size scale are especially shown in the following cases: electrical (higher electrical conductivity in ceramics), magnetic (increase of magnetic coercivity down to a critical grain size), mechanical (enhanced ductility, toughness, and formability of ceramics), optical (increase in luminescent efficiency of semiconductors). As shown in Figure 3 , a decrease of the particle radius leads to a lower melting point of gold, which gives a new characteristic for some applications in medicine and catalysis. Modification of the rate of evaporation at the melting point was considered by (Buffat, Borell, 1976, pp.2287-2297). 


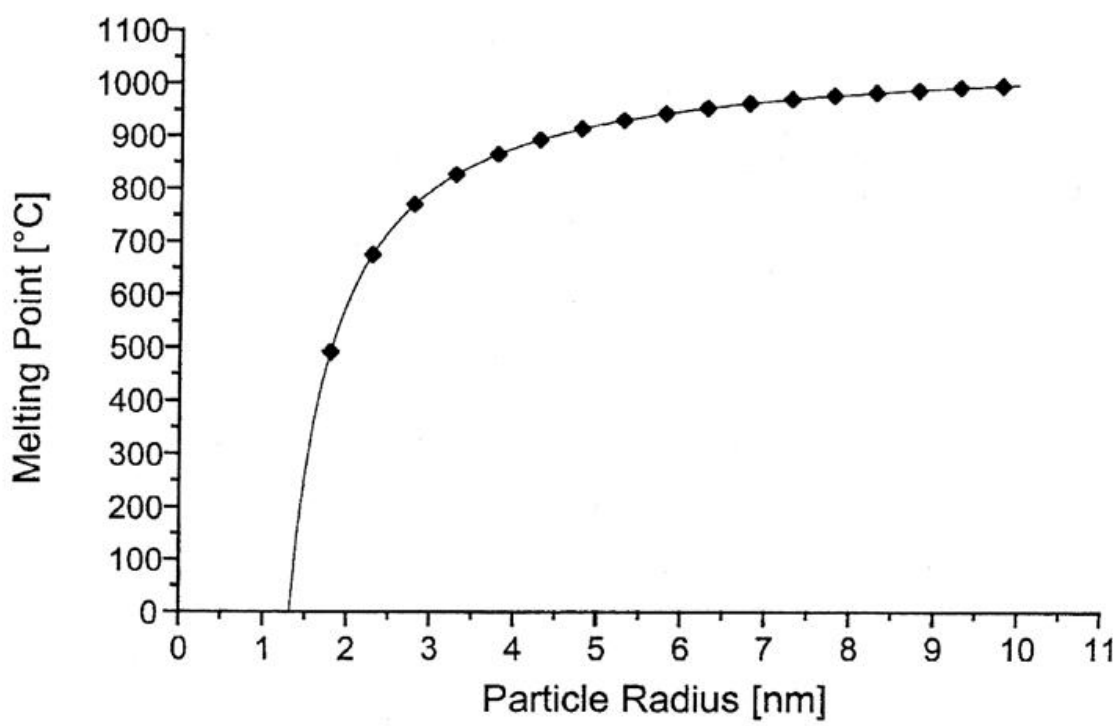

Figure 3 - Change of the melting point depending on the gold particle radius (Buffat, Borell, 1976, pp.2287-2297)

Slika 3 - Promena tacke topljenja u zavisnosti od precnika cestica zlata (Buffat, Borell, 1976, pp.2287-2297)

Together with a high degree of biocompatibility of gold, these structures show a potential in a wide variety of biological applications. It has also been speculated that they play role in a future cancer diagnosis and therapy. To improve early cancer detection, researchers are developing in vivo biomedical imaging techniques with the resolution to distinguish between healthy and malignant tissues. The examination of the journal literature and especially patents granted before 1978 by (Bond, 2008, pp.235-241) reveals frequent observation of the potential of gold as catalyst, some of which may inspire new directions for work on its applications. (Qi, 2008, pp.224-234) reported about the production of propylene oxide over nanogold catalysts in the presence of hydrogen and oxygen.

The synthesis of nanoparticles contains two different strategies: „TopDown" and "Bottom-Up“. The meaning of „Top-Down“ is based on mechanical grinding of initial materials to small dimensions (Raab, et al, 2008, pp.1-4).

It is necessary to decrease the powder size in order to perform HallPetch strengthening and apply a severe plastic deformation to powder particles to perform work hardening. High energy milling has a potential for realizing the new ideas of material designers, but experimental costs are high. The meaning of "Bottom-Up“ is related to the physico-chemical preparation methods. The precipitation methods are usually used for the purification of spent solution. 


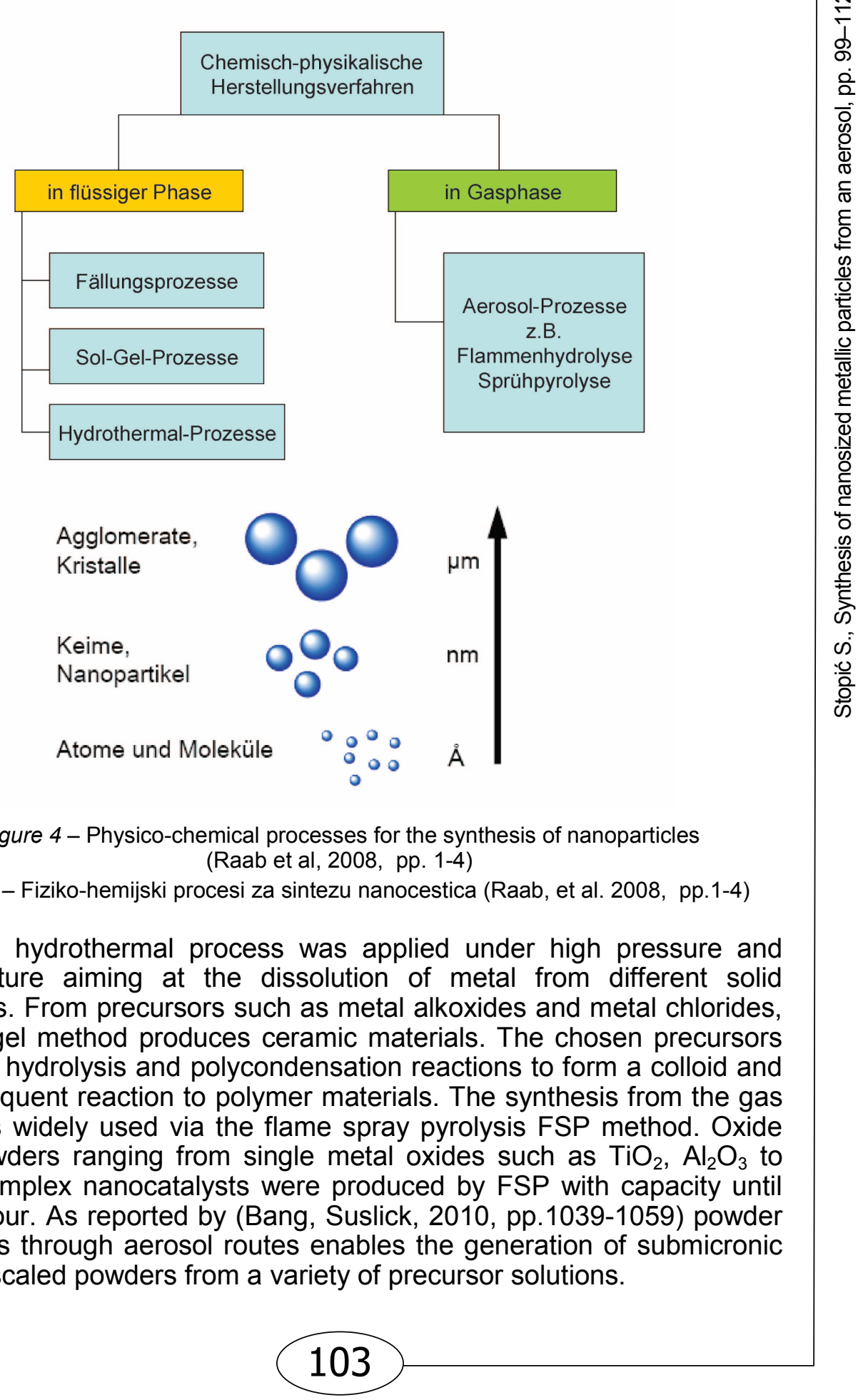




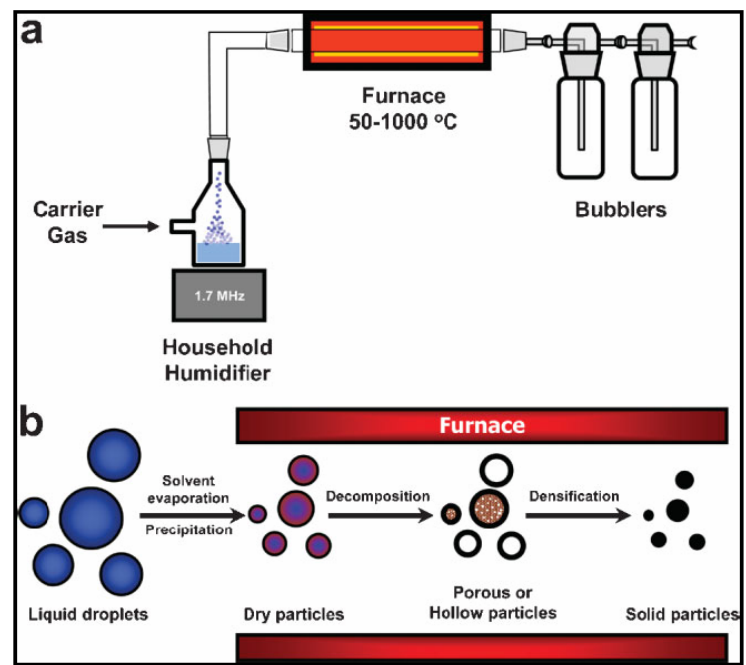

Figure 5 - a) USP-method (a) and b) mechanism of the USP synthesis (Bang, Suslick, 2010, pp.1039-1059)

Slika 5-a) USP-postupak i b) Mehanizam USP-Sinteze

(Bang, Suslick, 2010, pp.1039-1059)

The USP-process involves the formation of droplets of the precursor solution in a form of aerosol and a subsequent thermal decomposition in the hot reactor producing metal powders. Because of simplicity, easy to produce multicomponent materials, generation of spherical and un-agglomerated powders and the use of a variety of commercially available (inexpensive) precursors (metal nitrates, chlorides, acetates, sulphates), the USP has been chosen for the technique for the synthesis of metallic nanopowders. Spray pyrolysis is a useful tool for large-scale or small-scale production of particles with a controlled particle size because the final product properties can be controlled through the choice of precursor and solution concentration or by changing the aerosol decomposition parameters.

Generally, in the USP-process, a reaction temperature and a carrier gas are basic operating variables. In addition, solution properties such as precursor composition, concentration, or reducing agent may be crucial to achieve the desired product composition and morphology. Because of wide application, the preparation of different metal particles by the spray pyrolysis of metal salts is especially challenging. Using the aerosol synthesis, a single-step preparation process of catalytic materials is possible $\left(\mathrm{Au} / \mathrm{TiO}_{2}\right.$; $\mathrm{Ag} / \mathrm{TiO}_{2}$ ), thus avoiding separated steps such as drying and calcination, which are needed in "traditional" wet chemistry processes. The technical limitation of the USP- technique which is relatively low production rate (g per hour), will be especially considered in order to solve these problems. A small aerosol production and prepared nanopowder quantities by different atomizers were shown in Table 1. 
Table 1 - Analysis of the USP-process from $2 \mathrm{M} \mathrm{AgNO3}$ by (Pluym, et al, 1993, pp.383-392)

Tabela 1 - Analiza USP-procesa iz raznih generatora prikazanih u (Pluym, et al, 1993, pp.383-392)

\begin{tabular}{|c|c|c|c|c|}
\hline $\begin{array}{c}\text { Droplet } \\
(\mu \mathrm{m})\end{array}$ & $\begin{array}{c}\text { Aerosol } \\
\text { Production } \\
(\mathrm{ml} / \mathrm{h})\end{array}$ & $\begin{array}{c}\text { Theoretical production } \\
\text { rate per one transducer } \\
(\mathrm{g} / \mathrm{h})\end{array}$ & $\begin{array}{c}\text { Particle } \\
\text { size } \\
(\mu \mathrm{m})\end{array}$ & $\begin{array}{c}\text { Type of used } \\
\text { generator }\end{array}$ \\
\hline $0.5-0.7$ & 2.2 & 0.5 & $>0.4$ & TSI 3076 atomiser \\
\hline $0.2-0.5$ & 6 & 1.3 & 1.7 & $\begin{array}{c}\text { BGI collision } \\
\text { CN-25 generator }\end{array}$ \\
\hline $2.0-5.0$ & $10-12$ & 2.2 & 1.7 & $\begin{array}{c}\text { ultrasonic Pollenex } \\
\text { home humidifier }\end{array}$ \\
\hline
\end{tabular}

Some agglomeration and aggregation are mostly problems related to the finally prepared nanosized particles. The controlled synthesis of nanoparticles via the changing of the reaction parameters, especially of the carrier gas flow, is one way of preventing the agglomeration of particles. Because of the high reactivity of metallic nanopowders ("explosive combustion"), due to their large surface area, special care must be taken to the drying process.

\section{Comparison with different spray pyrolysis methods}

Nomenclature for spray pyrolysis (SP) processes is very different in literature: solution aerosol thermolysis, evaporative decomposition of solutions, ultrasonic spray decomposition, mist decomposition, spray roasting, chemical reactions with aerosols, plasma vaporizations of solutions, aerosol decomposition, spray hydrolysis. Concerning the atomizer used (pressure, ultrasonic, electrostatic, nebulizer) a variety of spray pyrolysis methods has been developed in the last 25 years. Regarding the characteristics of the used atomizers, the next processes are available as shown in Table 2:

Table 2 - Characteristics of the atomizers used for the SP method (Tsai, et al, 2004, pp.3647-3657)

Tabela 2 - Karakteristike atomizera korišćenih za raspršivanje (Tsai, et al, 2004, pp.3647-3657)

\begin{tabular}{|l|c|c|c|}
\hline \multicolumn{1}{|c|}{ Atomizer } & $\begin{array}{c}\text { Droplet size } \\
(\mu \mathrm{m})\end{array}$ & $\begin{array}{c}\text { Atomization rate } \\
\left(\mathrm{cm}^{3} / \mathrm{min}\right)\end{array}$ & $\begin{array}{c}\text { Droplet Velocity } \\
(\mathrm{m} / \mathrm{s})\end{array}$ \\
\hline Pressure & $10-100$ & $3-\mathrm{no}$ limit & $5-20$ \\
\hline Nebulizer & $0.1-2.0$ & $0.5-5$ & $0.2-0.4$ \\
\hline Ultrasonic & $\begin{array}{c}1-10(\mathrm{f}=0.8-2.5 \mathrm{MHz}) \\
10-100(\mathrm{f}=0.04-0.6 \mathrm{MHz})\end{array}$ & $<2$ & $0.2-0.4$ \\
\hline Electrostatic & $0.1-10$ & $<1$ & $<1$ \\
\hline $\begin{array}{l}\text { Ultrasound-modulated } \\
\text { two-fluid nozzle }\end{array}$ & $6-50$ & 5 & \\
\hline
\end{tabular}


By comparing ultrasound-modulated two-fluid atomization with conventional ultrasonic atomization techniques (Tsai, et al, 2004, pp.3647-3657), (Messing, et al, 1993, pp.2707-2726) reported that the particles are much smaller than those produced by the conventional USP- method. By reviewing publications by (Jung, et al, 2010, pp.16211645 ) in the last 25 years, the total number of papers is around 4800 , among which 3600 papers were published in the last 10 years. Based on the frequency of appearance in major journals, as shown in Fig. 6, the number of papers contributed from Asian countries exceeds the number of papers published by the colleagues from American and European countries. Although in the last 25 years the colleagues at the Institute of Technical Sciences of the Serbian Academy of Sciences and Arts together with The Vinca Institute of Nuclear Sciences have had approx. 500 international references related to spray pyrolysis, these data are missing in this publication by (Jung, et al, 2010, pp.1621-1645). Spray pyrolysis has been mostly used for many years for the production of ceramic powders. Many applications are presented in the automotive and food industries, environmental protection, chemicals and medicine.

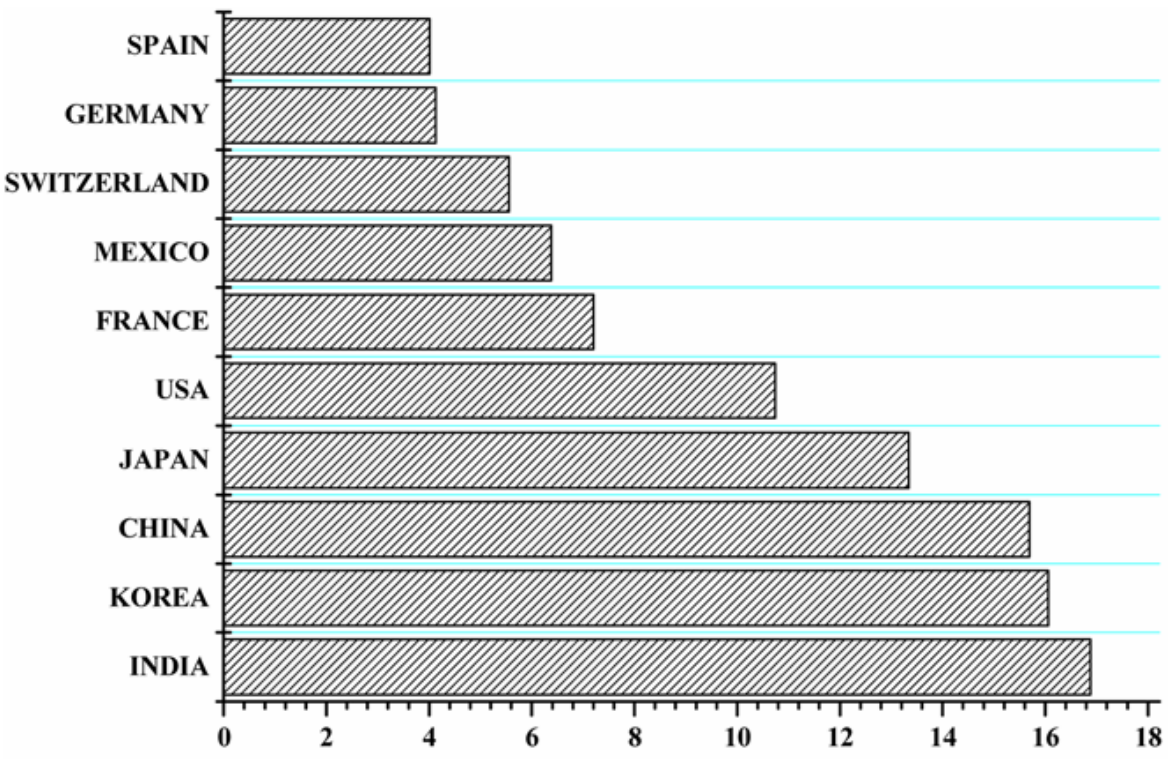

Percentage of spray pyrolysis-based published papers, $\%$

Figure 6 - Leading countries in the SP research for the last 10 years (Jung, et al, 2010, pp.1621-1645)

Slika 6 - Vodeće zemlje u istraživanju procesa raspršivanja u poslednjih 10 godina (Jung, et al, 2010, pp.1621-1645) 


\section{Ultrasound-modulated two-fluid (UMTF) atomization}

Ultrasound-modulated two-fluid (UMTF) atomization has a higher throughput and produces a narrower drop size distribution and a smaller peak drop diameter (the diameter where the peak of a drop-size distribution occurs) than conventional ultrasonic atomization (without air) at the same ultrasonic frequency. Ultrasonic generator, furnace with three different thermal zones, carrier-gas (air flow) and filter system for produced powders capture were the main components of the equipment in order to intensify the USP method. The equipment has been arranged using the ultrasonic generator, the gradient furnace, and the carrier-gas- system and the filter unit. Because the UMTF atomization produces more uniform drop size, heat and mass transfer rates are easier to manipulate, resulting in a greater control over the particle size during spray pyrolysis. By comparing the UMTF atomization with conventional ultrasonic atomization techniques (with both commercial ultrasonic nozzles and home-made ultrasonic nebulizers) and by varying the drop size (with peak diameters ranging from 7 to $55 \mu \mathrm{m}$ ), the study by (Tsai, et al, 2004, pp.3647-3657) examined quantitatively the relationship between the precursor drop size and the resulting particle size. They reported that the particles produced by the UMTF spray pyrolysis are much smaller than those produced by the conventional USP method. A careful subsequent comparison of precursor drop sizes to product particle sizes reveal that in addition to the conventionally-accepted one particle per drop mechanism, spray pyrolysis may also involve the gas to particle conversion mechanism, which creates nanoparticles much smaller than those predicted by the one particle per drop mechanism alone. A the same time, various droplet spray generators show some advantages and disadvantages.

Table 3 - Comparison of different atomization methods (Tsai, et al, 2004, pp. 3647-3657)

Tabela 3 - Poredjenje razlicitih metoda atomizacije

(Tsai, et al, 2004, pp. 3647-3657)

\begin{tabular}{|c|c|c|c|}
\hline Atomizer & $\begin{array}{c}\text { Generation } \\
\text { mechanism }\end{array}$ & Advantages & Disadvantages \\
\hline Pressure & $\begin{array}{c}\text { Shear force by } \\
\text { expansion of } \\
\text { pressurized liquid }\end{array}$ & High productivity & $\begin{array}{c}\text { Large size }(50 \mu \mathrm{m}) \\
\text { Hard to control size } \\
\text { and distribution }\end{array}$ \\
\hline Two-Fluid & $\begin{array}{c}\text { Shear force exerted on } \\
\text { liquid entrained by } \\
\text { expansion of } \\
\text { pressurized gas }\end{array}$ & $\begin{array}{c}\text { High productivity and } \\
\text { relatively easy to control } \\
\text { size and size distribution }\end{array}$ & $\begin{array}{c}\text { Low number of } \\
\text { concentration of } \\
\text { droplets }\end{array}$ \\
\hline
\end{tabular}




\begin{tabular}{|c|c|c|c|}
\hline Ultrasonic & $\begin{array}{c}\text { Shear force exerted by } \\
\text { ultrasonic cavitation } \\
\text { generated by the } \\
\text { piezoelectric disc }\end{array}$ & $\begin{array}{c}\text { Uniform droplets with } \\
\text { diameter less than } \\
10 \mu \mathrm{m} \\
\text { Easy to operate }\end{array}$ & $\begin{array}{c}\text { Not applicable to high } \\
\text { concentration or high } \\
\text { viscosity solution }\end{array}$ \\
\hline $\begin{array}{c}\text { Electrostatic } \\
\text { (Electrospray) }\end{array}$ & $\begin{array}{c}\text { Additional shear force } \\
\text { exerted by the electric } \\
\text { field formed by high } \\
\text { bias voltage between } \\
\text { the needle and the } \\
\text { substrate surface }\end{array}$ & $\begin{array}{c}\text { Charged droplets are } \\
\text { useful for thin film and } \\
\text { pattern formation }\end{array}$ & $\begin{array}{c}\text { Small productivity } \\
\text { Only for conducting } \\
\text { liquid }\end{array}$ \\
\hline $\begin{array}{c}\text { Ultrasound- } \\
\text { modulated } \\
\text { two-fluid } \\
\text { nozzle UMTF }\end{array}$ & $\begin{array}{c}\text { Combination of } \\
\text { pressurized expansion } \\
\text { of liquid and ultrasonic } \\
\text { cavitations }\end{array}$ & $\begin{array}{c}\text { Stable production of } \\
\text { droplets }\end{array}$ & Difficult to reduce \\
droplet size
\end{tabular}

Expansion of a pressurized liquid stream through a nozzle is the simplest method with a high productivity of droplets in the range of 50 $\mu \mathrm{m}$. A two fluid nozzle is similar to a pressurized nozzle except that a liquid is entered into the gas stream so that the shear force exerted on the liquid is larger than in a pressurized nozzle.

\section{Commercial application and perspective}

Although simple liquid atomization is a promising method to produce particles of controlled morphology and designed substructure, some commercial applications of spray pyrolysis have been slow. Only the following companies Degussa, Dupont and Cabot, have made many efforts in successful commercial applications. Dupont was successful in the production of silver paste for a plasma display panel in cooperation with SMP Company. $\mathrm{TiO}_{2}$ pigment was firstly produced via the spray hydrolysis process by BHP Billiton and finally developed by Altair in Reno, Nevada. The feed solution of titanium chloride was subjected to rapid evaporation to form amorphous, homogeneous, dense thin films. Two spray hydrolyzers are available in Reno, Nevada. The smaller has a capacity of $12 \mathrm{l} / \mathrm{h}$ and the larger processes $200 \mathrm{l} / \mathrm{h}$. The capacity of spray hydrolysis for Altair equipment corresponds to $40 \mathrm{~kg} / \mathrm{h} \mathrm{TiO}$ from a $120 \mathrm{~g} / \mathrm{l}$ Ti solution. Similar equipment is available industrially at a large scale, up to several tons/h in one unit. The Altair Company, Reno, has also developed a recipe to produce large batches of coated, non-photocatalytically active particles for use in cosmetic applications requiring a high degree of ultra violet absorption (Verlhust et al., 2002, pp. 85-94) 


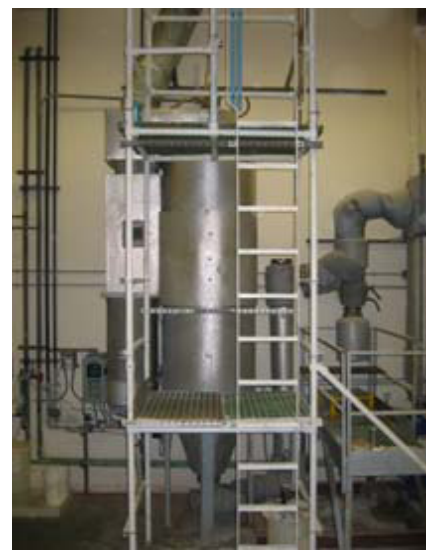

Figure 7 - Spray hydrolyser (Altair Nanomaterials Inc. Reno, Nevada) (Verlhust et al, 2002, pp. 85-94)

Slika 7 - Rasprsivanje vodenih rastvora (Altair Nanomaterials Inc. Reno, Nevada) (Verlhust et al, 2002, pp. 85-94)

Kodas has reported in US Patent 7128852 that using 1000 transducers produced $2 \mathrm{~kg} / \mathrm{h}$ submicron powder by the aerosol method (Verhulst, et al, 2002, pp.89-94). He ground the Superior MicroPowders, now Cabot corporation/USA for Inkjet application. In 2006 IME, RWTH developed a vertical USP-system, containing: Ultrasonic atomizer; reactor with 3 heating zones, electrostatic precipitator and scanning mobility particle sizer for online measurement of prepared nanoparticles.
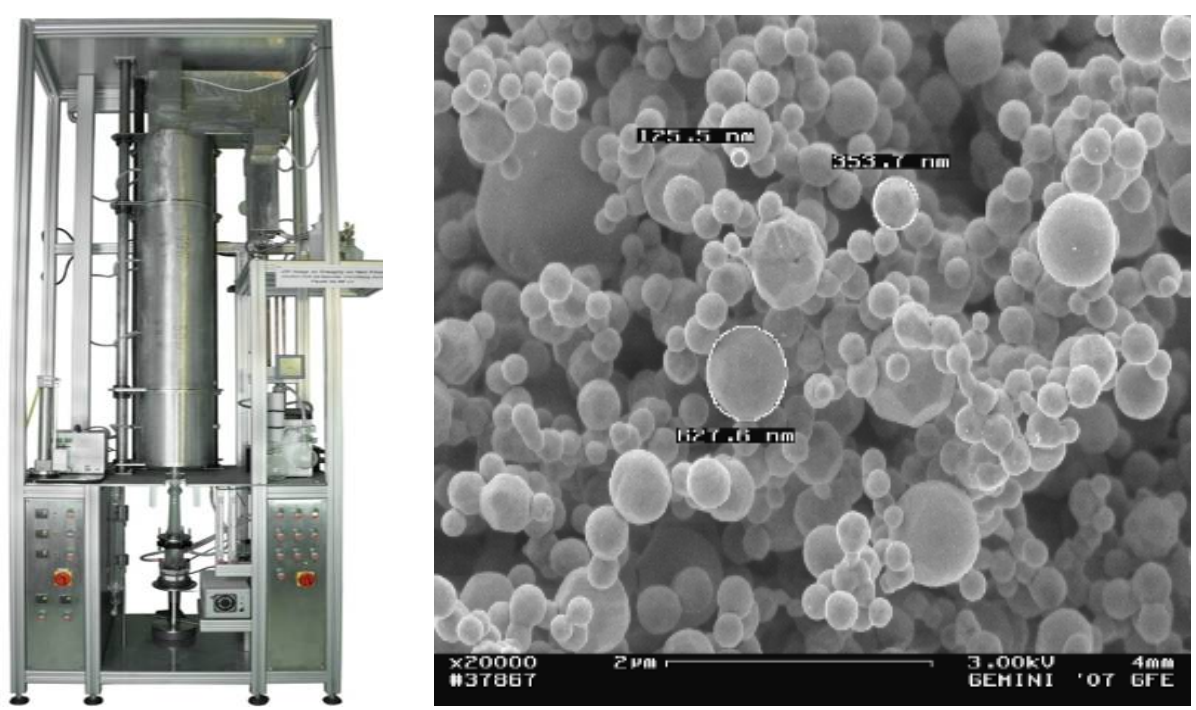

Figure 8 - USP-Synthesis at the IME, RWTH University/SEM analysis of nanosilver Slika 8 - USP-sinteza na IME, RWTH Univerzitetu/SEM analiza od nanosrebra 
Scale up of the USP was performed by IME, RWTH and ELINO Industrie-Ofenbau $\mathrm{GmbH}$, Düren as shown in Figure 9:
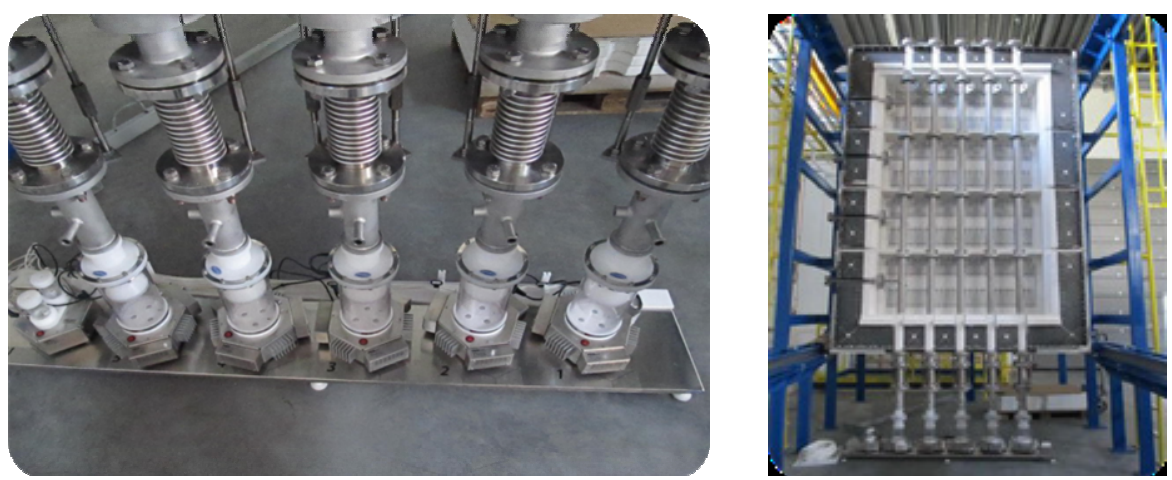

Fig. 9 - USP-generators \& wall heated reactors/Scale up of the USP-process (Matula, et al, 2013, pp.1-5)

Slika 9 - USP-generatori \& Reaktori/ Uvecana USP-proizvodnja (Matula, et al, 2013, pp.1-5)

Industrial scale for nanopowder production contains: A. system of five Aerosol ultrasonic generators, B. High-temperature furnace with 5 wall heated reactors, C. Two Electrostatic filters, D. Vacuum system. In cooperation with Elino $\mathrm{GmbH}$ engineers from Düren, Germany, and based on the previously built prototype in a micro scale by the IME Institute (Fig. 9), after nearly 6 months of intensive work of two teams: scientific one from the IME Institute and the engineering one from Elino $\mathrm{GmbH}$, the first design of a demo scale version of the device with working title "MIRANDA" was developed. The main engineering challenge was to transfer scientific achievements and maintain the process specifics in a macro scale in order to produce metallic nanosized particles (Kodas, et al, 2006).

\section{Conclusion}

Nanosized metal particles ( $\mathrm{Au}, \mathrm{Ag}, \mathrm{Cu}, \mathrm{Co})$ and their application in medicine, catalysis and electronics have been one of main research topics in the last decades at the IME, RWTH Aachen University. Because of simplicity, easy to produce nanosized spherical particles of metals and the use of a variety of inexpensive metal salts (nitrates, chlorides, acetates, sulphates), ultrasonic spray pyrolysis was preferred for this synthesis. On the other hand, industrial application of nanosized metals is still a challenge with a limited offer of methods suitable for a big scale 
production, especially when it comes to obtaining target morphology and complex composition. The scale up of the Ultrasonic Spray Pyrolysis (USP) process was successfully performed in Aachen by the IME, RWTH Aachen University and Elino $\mathrm{GmbH}$, Düren, Germany.

\section{Literature}

Bang, J.H., \& Suslick, K.S. 2010. Applications of Ultrasound to the Synthesis of Nanostructured Materials. Advanced Materials, 22(10), pp. 1039-1059. doi:10.1002/adma.200904093

BMBF. 2006. Nanotechnology, Innovations for the World in the Future, 52.

Bond, G. 2008. The early History of Catalysis by Gold. Gold Bulletin, 41(3), pp. 235-241. doi:10.1007/BF03214875

Buffat, P., \& Borel, J.P. 1976. Size Effect on the Melting Temperature of Gold Particles. Physical Review A, 13(6), pp. 2287-2298. doi:10.1103/PhysRevA.13.2287

Cammer, K. 2009. Nanotechnology: Ten Secrets of Innovation. Metall, 5(63), pp. 214-217.

Dittrich, R., Stopic, S., \& Friedrich, B. 2011. Mechanism of Nanogold Formation by Ultrasonic Spray Pyrolysis. . In: Proceeding of EMC 2011, Volume 3: Resources efficiency in the non-ferrous metals industry-optimization and improvement, Duesseldorf. , pp. 1065-1076

Jung, D.S., Park, S.B., \& Kang, Y.C. 2010. Design of Particles by Spray Pyrolysis and Recent Progress in its Application. Korean Journal of Chemical Engineering, 27(6), pp. 1621-1645. doi:10.1007/s11814-010-0402-5

Kodas, T., \& et al., 2006. Aerosol Method and Apparatus, particulate Products, and electronic Devices made therefrom, US Patent 7128852.

Lüchinger, N., Stark, W., \& Halim, S. 2010. Innovations in Health Care via Nanoparticles. GIT Labor-Fachzeitschrift, 1, pp. 89-101.

Matula, G., Bogovic, J., Stopic, S., \& Friedrich, B. 2013. Ultrasonic Spray Pyrolysis Equipment for Nanopowder Production- Part 1. Heat Processing, 1, pp. 1-5.

Messing, G.L., Zhang, S., \& Jayanthi, G.V. 1993. Ceramic Powder Synthesis by Spray Pyrolysis. Journal of the American Ceramic Society, 76(11), pp. 2707-2726. doi:10.1111/j.1151-2916.1993.tb04007.x

Pluym, T.C., Powell, Q.H., Gurav, A.S., Ward, T.L., Kodas, T.T., Wang, L.M., \& Glicksman, H.D. 1993. Solid Silver Particle Production by Spray Pyrolysis. Journal of Aerosol Science, 24(3), pp. 383-392. doi:10.1016/00218502(93)90010-7

Qi, C. 2008. The Production of Propylene Oxide over nanometer Au Catalysts in the presence of $\mathrm{H}_{2}$ and $\mathrm{O}_{2}$. Gold Bulletin, 41(3), pp. 224-234. doi:10.1007/BF03214874

Raab, C.M., Simkó, M., Fiedeler, U., Nentwich, M., \& Gazsó, A. 2008. Synthesis of Nanoparticles and Nanomaterials. Nano Trust Dossiers, 8(11), pp. 1-4.

Rittner, M.N., \& Abraham, T. 1998. Nanostructured Materials: An Overiew and Commercial Analysis. Journal of Metals, 1, pp. 37-47. 
Rudolf, R., Friedrich, B., Stopic, S., Anzel, I., Tomic, S., \& Čolić, M. 2012. Cytotoxicity of Gold Nanoparticles Prepared by Ultrasonic Spray Pyrolysis. Journal of Biomaterials Applications, 5, pp. 195-212.

Stopic, S., Friedrich, B., Volkov, T., \& Raic, K. 2010. Mechanism and Kinetics of Nanosilver Formation by Ultrasonic Spray Pyrolysis- Progress Report after a successful up-scaling. Metall, First part, 10, pp. 419-426.

Tsai, S.C., Song, Y.L., Tsai, C.S., Yang, C.C., Chiu, W.Y., \& Lin, H.M. 2004. Ultrasonic Spray Pyrolysis for Nanoparticles Synthesis. Journal of Materials Science, 39(11), pp. 3647-3657. doi:10.1023/B:JMSC.0000030718.76690.11

Verhulst, D., Sabacky, B., Spitler, T., \& Duyvesteyn, W. 2002. The Altair $\mathrm{TiO}_{2}$ Pigment Process and its Extension into the Field of Nanomaterials. CIM Bulletin, 95, pp. 89-94.

(1999) Retrieved from http://www.prizma.rs/ml/index.php/

\section{SINTEZA NANOČESTICA METALA IZ AEROSOLA}

OBLAST: materijali

VRSTA ČLANKA: pregledni članak

\section{Sažetak}

Sinteza nanočestica metala iz rastvora metalnih soli korišćenjem ultrazvučnog raspršivanja USP razmatrana je $u$ ovom radu. Preko kontrole procesnih parametara (površinski napon i gustina, koncentracija rastvora, vreme zadržavanja aerosola u reaktoru, protok gasa, temperatura razlaganja aerosola, vrste prekursora i zaštitna atmosfera) moguće je voditi proces u nameri da dobijemo prahove zahtevane morfologije, koja zadovoljava složene zahteve novih inženjerskih materijala. Značajna prednost je u poboljšanju karakteristika praha (manje čestice, bolja sferičnost, veća specifična površina) dobijena korišćenjem USP-procesa. USP-proces se izvodi delovanjem jakog izvora ultrazvuka na rastvor prekursora stvarajući aerosol sa konstantom veličinom kapi, koja zavisi od karakteristika tečnosti i frekvence ultrazvuka. Nastali aerosoli su transportovani nosećim gasom u reaktor na određenoj temperaturi, koji omogućava da se reakcija odvija u maloj zapremini čestice i formiranje nanočestica prahova. Nanoprahovi bakra, srebra, zlata i kobalta pripremljeni su sa poboljšanim fizičkim i hemijskim karakteristikama. Visoki troškovi proizvodnje i mala količina prahova jedno su ograničenje USP-procesa. Zato je uvećana proizvodnja jedan od najvažnijih ciljeva USP- procesa.

Key words: aerosol, nanočestice, ultrazvuk, sprej, piroliza, MMCT tranzicija

Datum prijema članka/Paper received on: 17. 03. 2013.

Datum dostavljanja ispravki rukopisa/Manuscript corrections submitted on:

21. 05. 2013.

Datum konačnog prihvatanja članka za objavljivanje/ Paper accepted for publishing on: 23. 05. 2013. 